\title{
Intangible Asset Moderation and the Sustainable Investment and Firm Value Relation
}

\author{
Perwito $^{1}$, Nugraha $^{2}$, Disman $^{3}$, Gunardi $^{4}$ \\ \{perwitoe@upi.edu ${ }^{1}$ \} \\ Computerized Accounting, Piksi Ganesha Polytechnic, 40274, Indonesia ${ }^{1,4}$ \\ Postgraduate Program, Universitas Pendidikan Indonesia, 40154, Indonesia ${ }^{1,2,3}$
}

\begin{abstract}
Sustainable investment in intangible assets provides opportunities to increase firm value. This study examines the moderation effect of intangible assets in sustainable investment to increase firm value. Public corporate in the telecommunication sector in Indonesia is the focus of this research, and a total of 23 data were observed. Proxy for measuring intangible assets using SG\&A expenses. To estimate and test model parameters used Process Macro for SPSS V3.4. The results showed that positively and significantly intangible assets sensible sustainable investment on firm value with proxy Return on Equity (ROE) and market to Book Value of Equity (MBVE). Corporations with intangible assets more perform better, prove and strengthen previous research that intangible assets add to firm value.
\end{abstract}

Keywords: Intangible assets, sustainable investment, firm value, SG\&A

\section{Introduction}

Global economic growth as a result of the Covid-19 outbreak decreased from 2.9 percent to 2.4 percent. If this disaster takes longer, it is predicted that economic growth will only be 1.5 percent [27], even many countries have experienced negative economic growth. This study analyzes the moderating role of intangible assets in the relationship between investment and firm value in the telecommunications sector. Since Covid-19, the telecommunications industry plays a significant role. There has been a shift in work patterns and public activities to become indirect.

Many information technology-based companies in Indonesia have a large market capitalization, for example, Gojek, Grab, Traveloka, Tokopedia, and Bukalapak. Service and technology-based companies' presence proves that intangible assets such as brands, patents, software, customer relationships, databases, innovative products, human resources, and distribution systems are increasingly important [23]. However, the extent of the capitalization value is challenging to identify because it is not presented in the balance sheet, making it challenging to become collateral when companies apply for bank loans. Intangible assets are significant and efficient in creating a company's competitive advantage, which leads to an increase in firm value.

The continuous growth of intangible investment is a hallmark of increasing developed countries' economies, initiating changes in business models, strategies and company performance negative relationship between investment and cash flow at a trim level company [18]. A positive relationship at a significant level company, an increase in cash flow will affect 
firm value8. Physical and intangible investment is equally good, but intangible capital adjusts more slowly with investment opportunities; Q-Tobin explained that intangible asset is much better than physical investment [23]. Productive, sustainable investment spending has a positive effect on firm value [12].

Along with the importance of intangible assets over time and serve as an additional factor to explain the firm value, it shows that higher intangible assets generally add to the firm. The proxies used to measure intangible assets in this study are previous studies using research and development $(\mathrm{R} \& \mathrm{D})$ expenditures $[4,10]$.

Share ownership in higher top management, entrepreneurial ability to manage the company and companies with many intangible assets will simultaneously increase the value of Tobin's Q [21]. The analysis shows that the size of intangible assets is a determinant of firm value. The proxy of intangible assets uses advertising and R\&D capital [10, 26]. Provides empirical evidence that intangible assets positively and significantly affect company performance as represented by ROA. The higher the intangible assets, the higher the dividends paid because they want to provide a positive signal for investors9. There is an increase in market capitalization value during mergers and acquisitions, and companies with more intangible assets have lower leverage [4].

The Contribution for this study are; first: shows that sustainable investment will be maximized if the corporate invests in intangible assets, second; proxies measure firm value using accounting-based; Return on Asset (ROA), Return on Equity (ROE), and market performance-based, Tobin's Q and the Market to Book Value of Equity (MBVE).

We compiled this article into; section 1 research background, section 2 describes contains data and methodology, section 4 discusses the results and discussion, section 5 conclusions.

\section{Method}

The analysis in this study uses a financial management approach. The research method used is the descriptive verification method. This study's population was telecommunications sector companies listed on the Indonesia Stock Exchange (IDX) in 2014-2019. The study's primary data used secondary data obtained from IDX, company annual reports, literature studies, scientific articles/journals, and corporate data publication.

Table 1. Sample Selection

\begin{tabular}{ll}
\hline \multicolumn{1}{c}{ Description } & \multicolumn{1}{c}{ Firm-year observations } \\
\hline Preliminary sample size (2014-2019) & 6 Emiten \\
& $\begin{array}{l}\text { Code Stock (Bakrie Telecom Tbk, XL Axiata Tbk, } \\
\text { Smartfren Telecom Tbk, Indosat Tbk, Jasnita } \\
\text { Telekomindo Tbk, Telekomunikasi Indoensia } \\
\text { (Persero) Tbk } \\
6 \times 6 \text { annual report: 36 observation }\end{array}$ \\
& 12 \\
Less & 1 \\
$\begin{array}{l}\text { Observations with incomplete data } \\
\text { Outliers data }\end{array}$ & $\mathbf{2 3}$ observation \\
\hline Total data observation Sample &
\end{tabular}


Firm Value measured using accounting-based; Return on Asset (ROA), Return on Equity (ROE) and market performance-based; Tobin's Q, and Market to Book Value of Equity (MBVE), this is consistent with prior studies [24,16,20]. The sustainable investment represents by capital expenditure [14]. The proxies used to measure intangible assets in this study are consistent with previous studies, selling, general, and administration (SG\&A) $[19,6,17,11,18,25]$. The operational variable of the research is Table 2.

Table 2. Definition of the research variables

\begin{tabular}{|c|c|}
\hline Variable & Description \\
\hline \multicolumn{2}{|l|}{ Dependent Variable } \\
\hline Return on assets (ROA) & The ratio of net income over the book value of average total assets [14] \\
\hline Return on equity (ROE) & The ratio of net income over the book value of average total equity [14] \\
\hline Tobin's-q & $\begin{array}{l}\text { The ratio of the sum market capitalization plus debt divided the total } \\
\text { assets [14] }\end{array}$ \\
\hline $\begin{array}{l}\text { Market-to-book value of } \\
\text { Equity (MBVE) or PBV } \\
\text { Independent Variable }\end{array}$ & The ratio of the sum market capitalization divided the total equity [14] \\
\hline \multirow{3}{*}{ Sustainable Investment } & Capital expenditure (Capex) [14] \\
\hline & $\begin{array}{l}\text { Alt-INVEST1: The change (from the beginning of the year to the end of the } \\
\text { year) in net fixed asset and depreciation, amortization scaled by } \\
\text { beginning-year total assets }\end{array}$ \\
\hline & $\begin{array}{l}\text { Alt-INVEST2: The change (from the beginning of the year to the end of the } \\
\text { year) in net fixed assets scaled by the beginning-year total assets. }\end{array}$ \\
\hline Moderation Variable & Selling, general and administrative (SG\&A) [17] \\
\hline
\end{tabular}

To test and estimate model parameters using Process Macro for SPSS V3.4. Conceptual and statistic diagram basic model is as follows;
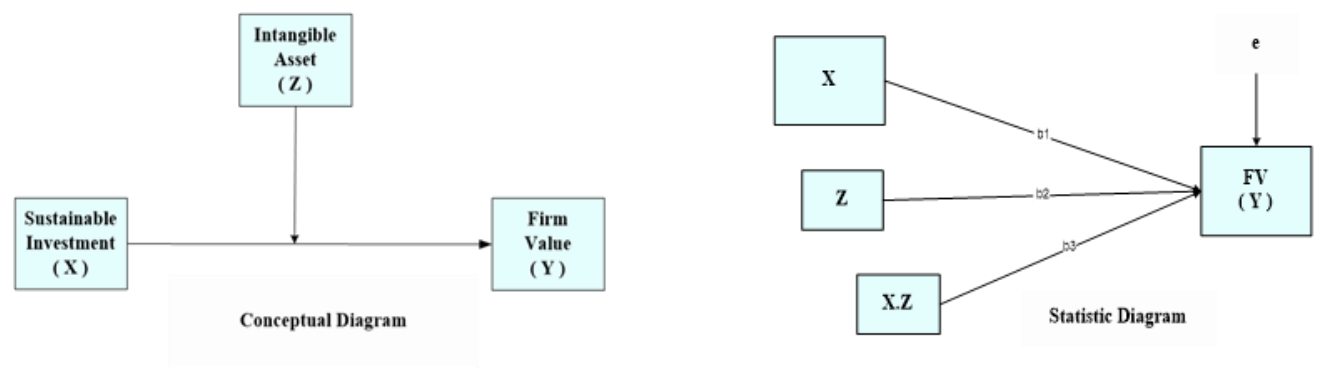

Fig. 1. Process Macro for SPSS V3.4.

$\mathrm{Y}=\mathrm{B}_{0}+\mathrm{B}_{1} \mathrm{X}+\mathrm{B}_{2} \mathrm{Z}+\mathrm{B}_{3} \mathrm{XZ}+\mathrm{e}$

$\begin{array}{lll}\text { ROA/ROE/Tobin's-Q/MBVE } & = & \alpha_{1}+\beta_{1} \text { Invest- } 1+\beta_{2} \mathrm{SG} \& A+\varepsilon_{i t} \\ \text { ROA/ROE/Tobin's-Q/MBVE } & = & \alpha_{2}+\beta_{1} \text { Invest- } 2+\beta_{2} \mathrm{SG} \& \mathrm{~A}+\varepsilon_{i t}\end{array}$




\section{Results and Discussion}

\subsection{Results}

Table 3. Description of Firm Value, Sustainable Investment, and Intangible

\begin{tabular}{lcccc}
\hline \multicolumn{1}{c}{ Variable } & Min & Max & Mean & St. Dev \\
\hline INVEST-1 & -14160 & 53394 & 15535.39 & 16360.61 \\
INVEST-2 & -14974 & 25278 & 5218.00 & 9875.72 \\
SG\&A & 252 & 10528 & 3631.61 & 3475.80 \\
ROA \% & -208.40 & 46.40 & -11.93 & 52.92 \\
ROE \% & -18.00 & 29.20 & 7.02 & 12.77 \\
Tobin's-q & .90 & 113.90 & 8.42 & 23.90 \\
MBVE & -394.70 & 4.70 & -36.00 & 91.42 \\
\hline
\end{tabular}

Base on Table 3, average invest-1 15535.39, average invest-2 5218.00, Average SG\&A 3631.61, Average ROA -11.93, Average ROE 7.02, Average Tobin's-Q 8.42, and average MBVE -36.00.

Table 4. Summary Statistic, Fixed effects regression results of Firm Value, Sustainable Investment, and Intangible Asset (Model Invest-1)

\begin{tabular}{|c|c|c|c|c|c|c|c|c|}
\hline \multirow{2}{*}{$\begin{array}{l}\text { Independent } \\
\text { Variable }\end{array}$} & \multicolumn{3}{|c|}{ Invest-1 R.Sq/F-value/ p-value } & \multicolumn{5}{|c|}{ Invest-1 R.Sq/F-value/ p-value } \\
\hline & ROA & ROE & Tobin's-Q & MBVE & ROA & ROE & Tobin's-Q & MBVE \\
\hline R.Sq & ,3595 & ,7248 & 2501 & ,4487 & 2960 & 7009 & 1445 & ,2878 \\
\hline F-value & 3,5544 & 16,6762 & 2,1120 & 5,1547 & 2,6629 & 14,8399 & 1,0695 & 2,5591 \\
\hline$p$-value & ,0340* &, $0000^{*}$ & 1325 & ,0089* & 0773 &, $0000^{*}$ & 3855 & ,0485* \\
\hline$S G \& A(+/-)$ & ,3281 & 3192 &,- 6392 & ,9390 & 3545 & ,3682 &,- 5156 & 7620 \\
\hline p-value & $(, 2391)$ & $(, 1456)$ & $(, 2116)$ & $(, 0360)^{*}$ & $(, 0932)$ & $(, 0286)$ & $(, 1843)$ & $(, 0347)^{*}$ \\
\hline R2-chng & 1377 & 0889 & 1513 & ,2456 & 1101 & 0713 & ,0696 & 1140 \\
\hline F-Chng & 4,0859 & 6,1352 & 3,8341 & 8,4634 & 2,9726 & 4,5320 & 1,5457 & 3,0402 \\
\hline $\mathrm{p}$-Value Chng & $0,0476^{*}$ &, $0228^{*}$ & 0,0651 &, $0090^{*}$ & 1009 & ,0466* & ,2289 &, $0497^{*}$ \\
\hline
\end{tabular}

Based on table 4, Sustainable investment using the Invest-1 proxy with ROA; the inclusion of the moderating variable (XZ) into the model can increase R2 by $13.77 \%$. The value of $\mathrm{F}$ change is 4.0859 , the p-value is 0.0476 , which means that intangible assets; moderator significantly moderates the relationship between sustainable investment and return on assets (ROA). Invest- 1 with ROE increases R 2 by $8.89 \%, F$ value of change is 6.1352 , the p-value is 0.0228 , which means that intangible asset moderators significantly moderate the relationship between sustainable investment and Return on Equity (ROE). Invest-1 with MBVE increases $\mathrm{R} 2$ by $24.56 \%$. F value of change is 8.4634 . The $\mathrm{p}$-value is 8.4634 , which means that intangible assets; moderator significantly moderates the relationship between sustainable investment and the Market to Book value of Equity (MBVE). However, the inclusion of the transcendental 
asset-moderating variable does not moderate the relationship between sustainable investment and Tobin's-Q.

Sustainable investment using the Invest-2 proxy with ROA, the inclusion of the moderating variable (XZ) into the model can increase R2 by $11.01 \%$, the value of $F$ change is 2.9726 . the p-value is 0.1009 , which means that the moderator of intangible assets does not significantly moderate the relationship between sustainable investment and return on assets (ROA). Invest-2 with ROE increases R2 by $7.13 \%$, F change value is 4.5320 , the p-value is 0.466 , which means that intangible assets moderator significantly moderates the relationship between sustainable investment and Return on Equity (ROE). Invest-2 with MBVE increases R2 by $11.40 \%$. F value of change is 3.0402. The p-value is 0.0497 , which means that intangible asset moderators significantly moderate the relationship between sustainable investment and Market to Book value of Equity (MBVE). However, the Invest-2 proxy with the inclusion of the intangible assetmoderating variable does not moderate the relationship between sustainable investment and Tobin's-Q.

The analysis results show that; Invest-1 and Invest- 2 proxies consistently show that intangible assets significantly moderate the relationship between sustainable investment and Return on Equity (ROE) and Market to Book value of Equity (MBVE). And intangible assets cannot reconcile the relationship between sustainable investment and Return on Assets (ROA) and Tobin's-Q.

\subsection{Discussion}

To strengthen this research, the theory that becomes the goal is; physical and intangible investment and the company's total value. This article corroborates previous research examining the empirical relationship between intangible investment and Tobin's q, positive relationship between investment in organizational capital and q7, indicating that brand capital investment and physical investment follow the economic or procyclical cycle [3].

Investment is an effort to obtain cash flow estimates to maintain the company's sustainability and performance. There is a positive relationship between investment and cash flow1. The positive effect of investing activities will increase firm value [22]. Investment is positively related to cash flow and Tobin's Q. Both Q and investment move in the same direction as expected in income growth, so changes in expected income growth encourage $Q$ and investment to move positively [1]. Productive, sustainable investment spending has a positive effect on firm value [12].

The sustainable growth of intangible investment is a hallmark of improving developed countries' economies, initiating business models, strategies, and company performance [18]. The results showed that intangible assets were able to moderate and significantly impact the relationship between sustainable investment and firm value with the Proxy of Return on Equity (ROE) and Market to Book value of Equity (MBVE). Physical and intangible investments are just as good; the intangible asset is much better than the physical investment [23]. There is a higher investment-cash flow sensitivity for companies that use intangible assets [2].

Provide empirical evidence showing a positive and significant relationship between R\&D expenditure and market value [15]. Intangible assets over time serve as an additional factor to explain the firm value, suggesting that higher intangible assets generally add to firm value [4, 21]. Empirical evidence that intangible assets have a positive and significant effect on company performance as represented by ROA and the increase in intangible assets, dividends are paid because the company wants to provide a positive signal for investors9.

The measure of intangible assets is a determinant of firm value, a proxy for intangible assets using advertising and R\&D capital $[10,26]$. There is an increase in market capitalization value 
at mergers and acquisitions, and companies with more intangible assets have lower leverage4. However, intangible assets cannot explain the relationship between Company Performance and Company Market Value [28,17].

Based on the results of the study indicates the importance of companies investing in intangible assets. In the telecommunications industry, spending on human resource development to transform into a digital culture is essential. You have high agility at work and have the competence of digital talents who can develop digital product innovations. Also, researches that lead to company patents and trademarks are expected to be able to lift the company's image so that, in the end, it will increase the company's value. Along with the development of information and communication technology today, market perceptions are influenced by intangible investments.

\section{Conclusion}

The conclusions of this studies are; the inclusion of intangible asset moderation in the survey has significantly and positive moderate the relationship of sustainable investment with firm value with the proxies of Return on Equity (ROE) and Market to Book value of Equity (MBVE), but was unable to moderate the Return on Assets (ROA) and Tobin's -Q. The importance of investing in intangible assets and dynamic advantages that continuously adapt to changes and the needs of information and communication technology. Limitation: This research does not reflect the overall stock exchange performance. It is because only in the telecommunications sector, the 2014-2019 study period. Study Forward: Based on the data analysis results, the suggestions for this study are; 1) broadening the scope of research objects in public companies in Indonesia and the period of research. 2) Proxy to a measured intangible asset used R\&D costs. 3) Moderation and mediation of research variables that can increase the relationship between investment and firm value. 4) For public companies, it is necessary to update policies, business processes, data preparation, and financial systems to ensure the accuracy of applying the IFRS standard, which is quite complex.

\section{Acknowledgments}

The highest gratitude and appreciation to the Piksi Ganesha Polytechnic, Postgraduate School of the Universitas Pendidikan Indonesia (UPI), lecturers support the subjects and those who have helped complete the research.

\section{References}

[1] Abel, A. B., \& Eberly, J. C. (2011). How Q and cash flow affect investment without frictions: An analytic explanation. Review of Economic Studies, 78(4), 1179-1200. https://doi.org/10.1093/restud/rdr006.

[2] Almeida, H., \& Campello, M. (2007). Financial constraints, asset tangibility, and corporate investment. Review of Financial Studies, 20(5), 1429-1460. https://doi.org/10.1093/rfs/hhm019

[3] Belo, F., Lin, X., \& Ana, M. (2014). Review of Economic Dynamics Brand capital and firm value

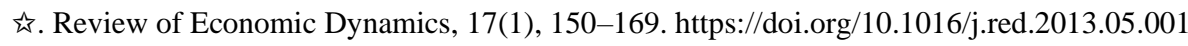


[4] Clausen, S., \& Hirth, S. (2016). Measuring the value of intangibles. Journal of Corporate Finance, 40, 110-127. https://doi.org/10.1016/j.jcorpfin.2016.07.012

[6] Eisfeldt, A. L., \& Papanikolaou, D. (2013). Organization capital and the cross-section of expected returns. Journal of Finance, 68(4), 1365-1406. https://doi.org/10.1111/jofi.12034

[7] Eisfeldt, A. L., \& Papanikolaou, D. (2014). The value and ownership of intangible capital. American Economic Review, 104(5), 189-194. https://doi.org/10.1257/aer.104.5.189

[8] Firth, M., Malatesta, P. H., Xin, Q., \& Xu, L. (2012). Corporate investment, government control, and financing channels: Evidence from China's Listed Companies. Journal of Corporate Finance, 18(3), 433-450. https://doi.org/10.1016/j.jcorpfin.2012.01.004

[9] Gamayuni, R. R. (2015). The Effect Of Intangible Asset, Financial Performance And Financial Policies On The Firm Value. 4(01), 202-212.

[10] Gleason, K. I., \& Klock, M. (2006). Intangible capital in the pharmaceutical and chemical industry. The Quarterly Review of Economics and Finance, 46, 300-314. https://doi.org/10.1016/j.qref.2005.03.001

[11] Gu, F., \& Lev, B. (2017). Time to Change Your Investment Model. Financial Analysts Journal, 73(4), 23-33. https://www.bloomberg.com/news/articles/2017-10-13/amazon-is-said-to-makesportswear-push-in-industry-rattling-move

[12] Hidayat, R., Wahyudi, S., Muharam, H., \& Zainudin, F. (2020). Institutional ownership, sustainable productivity investment based on financial constraints and firm value: Implications of agency theory, signaling theory, and asymmetry information on sharia companies in Indonesia. International Journal of Financial Research, 11(1), 71-81. https://doi.org/10.5430/ijfr.v11n1p71

[13] Jensen, M. (1986). Agency Costs of Free Cash Flow, Corporate Finance, and Takeovers. The American Economic Review, 76(2), 323-329. http://www.jstor.org/stable/1818789.

[14] Jiang, F., Cai, W., Wang, X., \& Zhu, B. (2018). Multiple large shareholders and corporate investment: Evidence from China. Journal of Corporate Finance, 50(2017), 66-83. https://doi.org/10.1016/j.jcorpfin.2018.02.001

[15] Johnson, L. D., \& Pazderka, B. (1993). Firm value and investment in R\&D. Managerial and Decision Economics, 14(1), 15-24. https://doi.org/10.1002/mde.4090140103

[16] Kao, M. F., Hodgkinson, L., \& Jaafar, A. (2018). Ownership structure, the board of directors and firm performance: evidence from Taiwan. Corporate Governance, 19(1), 189-216. https://doi.org/10.1108/CG-04-2018-0144

[17] Klock, M., \& Megna, P. (1993). The impact of intangible capital on Tobin's q in the semiconductor industry. American Economic Review, 83(2), 265-269. https://doi.org/10.2307/2117675

[18] Lev, B. I. (2018). INTANGIBLES. SSRN Electronic Journal ., July. doi:10.2139/ssrn.3218586

[19] Lev, B., \& Radhakrishnan, S. (2005). The Valuation of Organization Capital. In Measuring Capital in the New Economy (Issue August). https://doi.org/10.7208/chicago/9780226116174.003.0004

[20] Mollah et al. (2012). Ownership structure, corporate governance, and firm performance. Studies in Economics and Finance, 29(4), 301-319. https://doi.org/10.1108/10867371211266937

[21] Morck, R., Shleifer, A., \& \& Vishny, R. W. (1988). Management ownership and market valuation. An empirical analysis. Journal of Financial Economics, 20(C), 293-315. https://doi.org/10.1016/0304-405X(88)90048-7

[22] Myeong, \& Hyeon, C. (1998). Ownership structure, investment, and the corporate value: an empirical analysis. Journal of Financial Economics, 47, 103-121.

[23] Peters, R. H., \& Taylor, L. A. (2017). Intangible capital and the investment-q relation. Journal of Financial Economics, 123(2), 251-272. https://doi.org/10.1016/j.jfineco.2016.03.011

[24] Rashid, M. M. (2020). "Ownership structure and firm performance: the mediating role of board characteristics." Corporate Governance (Bingley), 20(4), 719-737. https://doi.org/10.1108/CG-022019-0056

[25] Sun, Q., \& Xiaolan, M. Z. (2019). Financing intangible capital R. Journal of Financial Economics, 133(3), 564-588. https://doi.org/10.1016/j.jfineco.2019.04.003

[26] Tsai, C. F., Lu, Y. H., \& Yen, D. C. (2012). Determinants of intangible assets value: The data mining approach. Knowledge-Based Systems, 31, 67-77. https://doi.org/10.1016/j.knosys.2012.02.007 
[27] Vaughan, A. (2020). World braces for economic impact. New Scientist, 245(3272), 10. https://doi.org/10.1016/s0262-4079(20)30477-2

[28] Widiantoro, D. M. (2012). Measuring the Impact of Intangible Asset Investment Toward Company Financial Health and Company Agency Problem: Empirical Research from Indonesian. Journal of $\begin{array}{llll}\text { Finance and Risk } \quad \text { Perspectives, } & 1(2),\end{array}$ http://papers.ssrn.com/sol3/papers.cfm?abstract_id=2078900 